\title{
ANALISIS NETNOGRAFI SENTIMEN PENGGUNA TWITTER TERHADAP PEMBUKAAN KEMBALI PARIWISATA DI TENGAH PANDEMI COVID-19
}

\author{
Aditya Rizki Rinaldi' ${ }^{1}$, Dyah Mutiarin ${ }^{2}$, Janianton Damanik ${ }^{3}$ \\ ${ }^{l}$ Universitas Gadjah Mada, Yogyakarta, Indonesia, Email: aditya.rizki.rinaldi@mail.ugm.ac.id \\ ${ }^{2}$ Universitas Muhammadiyah Yogyakarta, Yogyakarta, Email: mutiarin@umy.ac.id \\ ${ }^{3}$ Universitas Gadjah Mada, Yogyakarta, Indonesia, Email: antondmk@ugm.ac.id
}

\begin{abstract}
ABSTRAK
Pemerintah dituntut untuk sigap dalam menindaklanjuti penyebaran Covid-19, di sisi lain pemerintah diminta untuk menstabilkan perekonomian masyarakat, sehingga pemerintah membuka kembali akses dan industri pariwisata. Opini publik dapat terbentuk dengan mudah melalui sentimen yang tertuang secara online (dalam jaringan), sehingga untuk mengantisipasinya dapat dilakukan melalui eksplorasi konten media sosial. Penelitian ini dilakukan dengan mengeksplorasi sentimen masyarakat khususnya warganet terkait kebijakan pembukaan kembali pariwisata di Indonesia di tengah pandemi Covid-19, untuk menelusuri opini publik di Indonesia. Pendekatan kualitatif digunakan dalam penelitian ini dengan analisis netnografi untuk menganalisis postingan atau tulisan warganet di media sosial Twitter. Pengambilan data media sosial Twitter diambil menggunakan bantuan dari platform Google Chrome yaitu NCapture, dan data dikelola menggunakan perangkat lunak NVivo 14 sebagai alat pengelolaan penelitian kualitatif. NCapture menemukan 513 postingan dengan penyaringan kata "wisata baru". Hasil penelitian terhadap 297 postingan menunjukkan sikap netral atau sikap tidak berpihak dari warganet pengguna Twitter. Berdasarkan hasil analisis tersebut, terdapat temuan yang menunjukkan sumber-sumber dari konten Twitter dengan sentimen negatif maupun positif, dimana akun pemerintah diketahui tidak menjadi sumber dalam postingan dengan sentimen negatif. Temuan sentimen warganet di Twitter dapat menjadi arahan dalam mengetahui sikap dan respon masyarakat terhadap kebijakan dalam pembukaan kembali pariwisata di tengah pandemi Covid-19. Hasil analisis menunjukkan sebagian besar warganet memberikan sentimen netral terkait pembukaan kembali pariwisata atau berada pada posisi tidak memihak. Penelitian ini juga menunjukkan beberapa kata dan frasa yang sering muncul seperti "wisata", "buka" dan "protokol kesehatan". Menariknya, hasil temuan penelitian ini menunjukkan di antara akun Twitter yang ada hanya akun pemerintahan yang tidak memiliki sentimen negatif dalam tweet yang dibuatnya.
\end{abstract}

Kata Kunci: Covid-19, Pembukaan Kembali Pariwisata, Analisis Sentimen

\section{NETNOGRAPHIC ANALYSIS OF TWITTER USER SENTIMENT ON TOURISM REOPENING AMID THE COVID-19}

\begin{abstract}
The government is required to be alert in following up on the spread of Covid-19, on the other hand the government is asked to stabilize the community's economy, so that the government reopens access and the tourism industry. Public opinion can be formed easily through
\end{abstract}


sentiments expressed online (in the network), so that to anticipate this can be done through exploration of social media content. This research was conducted by exploring public sentiment, especially citizens regarding the policy of reopening tourism in Indonesia in the midst of the Covid-19 pandemic, to explore public opinion in Indonesia. A qualitative approach is used in this study with netnographic analysis to analyze warganet posts or writings on Twitter social media. Twitter social media data collection is taken using the help of the Google Chrome platform, namely NCapture, and the data is managed using NVivo 14 software as a qualitative research management tool. NCapture found 513 posts filtering the word "new travel". The results of the study on 297 posts showed a neutral or impartial attitude from Twitter users. Based on the results of this analysis, there are findings that show sources of Twitter content with negative or positive sentiments, where government accounts are known not to be the source of posts with negative sentiments. The findings of netizen sentiment on Twitter can be a direction in finding out people's attitudes and responses to policies in reopening tourism in the midst of the Covid-19 pandemic. The results of the analysis show that most netizens provide neutral sentiment regarding the reopening of tourism or are in an impartial position. This study also pointed out some of the words and phrases that often appear such as "travel", "open" and "health protocol". Interestingly, the findings of this study show that among Twitter accounts there are only government accounts that do not have negative sentiments in the tweets they make.

Keywords : Covid-19, Re-opening Tourism, Sentiment Analysis

Copyright @2021. UHN IGB Sugriwa Denpasar. All Right Reserved penyebaran meluas ke beberapa kota lainnya

\section{PENDAHULUAN}

Coronavirus Disease 2019 atau dikenal dengan sebutan Covid-19 dinyatakan sebagai pandemi oleh Organisasi Kesehatan Dunia (World Health Organization/WHO) pada tanggal 11 Maret 2020 (Maulida et al., 2020). Dalam runtun waktu tersebut beberapa negara telah merumuskan, menyusun, dan menjalankan beberapa regulasi, dan strategi guna mempertahankan ketahanan negaranya dalam menghadapi dan mengendalikan penyebaran Covid-19, berbeda dengan pemerintah Indonesia menunjukkan ketidak tanggapan pada mula penyebaran virus di dunia, dan cenderung memiliki sikap serta pandangan yang berbeda, dimana memiliki keyakinan bahwa Indonesia akan terhindar dari penyebaran Covid-19 (Agustino, 2020). Sehingga berbeda dengan beberapa negara lainnya di ASEAN, Indonesia menggagaskan strategi pemberian intensif bagi sektor pariwisata dalam peningkatan kunjungan wisatawan mancanegara, namun gagasan ini tidak terealisasikan setelah ditemukan kasus pertama dimana terdapat warga negara Indonesia yang terinfeksi virus tersebut, dan
(Agustino, 2020; Yurianto et al., 2020).

Kondisi pariwisata semakin tidak stabil dan diperparah dengan adanya kebijakan Travel Warning, dengan dalih meningkatkan kunjungan wisatawan mancanegara ke Indonesia, pemerintah Indonesia menyusun rencana strategis pada bulan Februari untuk mengucurkan dana untuk media dan influencer baik influencer Indonesia atau luar negeri (Santia, 2020; Wahyudi, 2020). Selain untuk mengantisipasi sepinya wisatawan sebagai dampak dari penyebaran Covid-19, intensif yang diberikan kepada influencer ini diharapkan dapat menarik wisatawan mancanegara yang tidak dapat/batal melakukan perjalanan di negara-negara yang telah melakukan karantina wilayah/lockdown untuk berkunjung ke Indonesia, melalui pemanfaatan platform media sosial dan internet (CNBC Indonesia, 2020; Santia, 2020). Seiring dengan waktu, walaupun untuk penyebaran dan tingkat kematian akibat Covid-19 serta dampak ekonomi tidak dapat dihindari oleh pemerintah, kewajiban pemerintah untuk memaksimalkan usaha mempertahankan dan menjaga masyarakatnya dari pandemi dengan menerapkan 
kewenangan pemerintah dalam penerapan kebijakan publik (Anderson et al., 2020; Parsons, 2008).

Kebijakan yang diterapkan oleh Pemerintah Indonesia setelah penetapan Covid-19 sebagai pandemi oleh WHO adalah penerapan kebijakan pembatasan sosial berskala besar (PSBB) yang dimulai pada tanggal 31 Maret 2020 bersamaan dengan penerbitan Peraturan Peraturan Menteri Kesehatan Nomor 9 Tahun 2020 Tentang Pedoman Pembatasan Berskala Besar (PSBB) (Peraturan Menteri Kesehatan Nomor 9 Tahun 2020 Tentang Pedoman Pembatasan Berskala Besar (PSBB), 2020). Kebijakan lainnya yang dicanangkan oleh pemerintah antara lain program 3M (memakai masker, mencuci tangan, dan menjaga jarak) dimana hal ini merupakan perpanjangan dari himbauan pembatasan sosial (social distancing) dan pembatasan fisik (physical distancing). Berbeda dengan beberapa negara lain di dunia yang menerapkan. kebijakan lockdown, sehingga selama pembatasan sosial masyarakat semakin aktif menyuarakan kritik dan sindirian yang dilontarkan baik kepada pemerintah ataupun kepada individu lain yang dianggap tidak mematuhi himbauan pemerintah (Syarifuddin, 2020).

Hal ini menunjukkan bahwa langkah yang diambil pemerintah dapat menjadi sebuah bumerang dimana menggiring opini negatif masyarakat mengenai ketidaktanggapan pemerintah atau bahkan ketiadaan prioritas pemerintah dalam menangkal penyebaran Covid-19 (Agustino, 2020; Harirah \& Rizaldi, 2020). Opini publik akan mudah terbentuk apabila adanya kelemahan pada respon darurat yang memungkinkan suatu negara berada pada posisi krisis darurat pubik, bentuk kritikan dan sindiran yang pernah terjadi di Indonesia adalah cuitan masyarakat melalui platform media sosial yang menyuarakan untuk diberlakukannya lockdown (Alizah et al., 2020; Ning, 2020). Perkembangan teknologi yang pesat membantu mempermudah pendeteksian sentimen msayarakat melalui dunia internet, dimana data-data yang dihasilkan dari pengukuran sentimen masyarakat dapat digunakan untuk memperoleh temuan mengenai bagaimana suatu kelompok masyarakat merespon suatu fenomena yang terjadi di sekitarnya (Indartoyo et al., 2020).

Salah satu media sosial, yang sering digunakan adalah Twitter, di Indonesia tren penggunaan media sosial ini kembali diminati berbarengan dengan adanya pandemi Covid19 dan merupakan media sosial dengan pengguna terbanyak di Indonesia (Napitupulu et al., 2020; Pratama, 2020). Penggunaan Twitter di Indonesia yang meningkat pada waktu pandemi ini, memungkinkan masyarakat atau yang lebih dikenal dengan warganet untuk mendapatkan informasi, pengetahuan, pembaharuan informasi, media menyebarkan pendapat, saran, kritik dan bahkan sindiran (Alkatiri et al., 2020; Napitupulu et al., 2020). Peranan media sosial sebagai perantara informasi serta pembentukan sebuah topik, masalah dan informasi penting lainnya dalam pembentukan opini publik menjadi sangat penting pada masa dimana pembatasan sosial dan fisik diterapkan. Sehingga masyarakat akan lebih merasa nyaman untuk memahami dan mengekspresikan kekhawatiran serta pertanyaan umum lainnya namun di sisi lain akan memudahkan masyarakat terpengaruh isu-isu atau situasi yang terbentuk dari kolektivitas opini yang bermunculan melalui jejaring media sosial (Alkatiri et al., 2020; Shorey et al., 2020; Syarifuddin, 2020). Kecepatan dan ketepatan waktu dalam proses penyebaran opini melalui media sosial, memberikan keefektifan dalam pembentukan opini publik. Dengan mengacu pada perasaan kolektif suatu komunitas terhadap sebuah masalah atau isu tertentu yang dihadapi, maka penyebaran serta reaksi yang luas terhadap sebuah informasi dapat menyebabkan rangkaian tindakan dan respon yang tidak tepat, bahkan dapat menimbulkan sebuah tekanan yang terbentuk akibat opini publik terhadap pemerintahan, serta kehidupan bersosial (Ning, 2020; Syarifuddin, 2020).

Mengikuti perkembangan kondisi pandemi Covid-19, terdapat penelitian yang membahas mengenai opini publik terhadap 
penerapan New Normal, yang menunjukkan temuan bahwa opini publik secara daring melalui cuitan Twitter memiliki kecenderungan berisi tulisan dengan sifat negatif, yang mengarah pada penolakan warganet terhadap penerapan new normal dan mempertanyakan ketegasan dari penegakan kebijakan tersebut (Alkatiri et al., 2020). Bentuk penerapan "new normal" pada sektor pariwisata adalah dibukanya kembali akses berwisata dan pintu masuk beberapa daya tarik wisata. Pemerintah pusat maupun daerah telah mempersiapkan objek daya tarik wisata yang dibuka kembali pada masa pandemi. Penerapan protokol kesehatan menjadi jawaban untuk menjawab isu kekhawatiran masyarakat akan keselamatan dan kesehatan serta untuk tetap menjalankan roda ekonomi sektor pariwisata (N. R. Aditya, 2020; Ihsanuddin, 2020). Dicky Budiman seorang epidemiolog, dalam Shalihah (2020) menyinggung kebijakan pembukaan pariwisata merupakan hal yang keliru, dikarenakan seharusnya objek daya tarik wisata menjadi lokasi/tempat ataupun objek yang ditempatkan di fase terakhir dalam penerapan kebijakan pelonggaran. Penerapan kebijakan yang diterapkan selama pandemi Covid-19 oleh pemerintah Indonesia, telah menarik minat dan ketertarikan peneliti mengenai opini publik (H. Aditya et al., 2020; Alizah et al., 2020; Hanafi \& Ferdiansyah, 2020; Rahma et al., 2020), namun masih belum ada yang meneliti mengenai opini publik terhadap pembukaan kembali pariwisata di kala pandemi Covid-19.

Meskipun penerapan new normal telah diberlakukan dari bulan Mei 2020, dan beberapa objek daya tarik wisata telah membuka pintu masuk untuk wisata dan menerapkan protokol kesehatan. Bagaimana opini warganet terhadap pembukaan kembali pariwisata di tengah pandemi Covid-19, maka penelitian ini dilakukan untuk menjawab beberapa pertanyaan. Pertama, perlu adanya kajian mengenai gambaran dari setiap pengguna Twitter baik pribadi, komunitas, pemerintah dan media sosial dalam menyajikan konten terkait dengan pembukaan pariwisata di tengah pandemi Covid-19 pada sosial media. Selanjutnya, bagaimana respon individu terhadap fenomena, baik kepada pihak penegak kebijakan serta kepada masyarakat umum, melalui penganalisisan sentimen masyarakat yang pada kasus ini dikenal dengan warganet. Pembukaan pariwisata kembali sebagai bentuk kebijakan dengan tujuan untuk mempertahankan perekonomian, mendapatkan respon pro dan kontra yang secara spesifik dapat diketahui menggunakan analisis sentimen masyarakat, dimana pada penelitian ini akan dilakukan dengan metode netnografi.

\section{METODE}

Metode kualitatif yang digunakan dalam penelitian ini adalah metodologi interpretasi netnografi, dikenal sebagai salah satu bentuk dari penelitian etnografi dengan pengadaptasian untuk mengkaji pemahaman seputar kehidupan di dunia internet, termasuk media sosial, yang didasarkan pada pengamatan tekstual. Netnografi menjadi sebuah metode yang digunakan dalam mempelajari ruang cybernetics atau yang dikenal dengan dunia maya, yang baru-baru ini menjadi suatu metode khusus yang dirancang dalam mempelajari budaya komunitas daring (Ahuja \& Shakeel, 2017; Bowler Jr, 2010; Kozinets, 2015). Penelitian ini dilakukan dengan menganalisis sentimen masyarakat/warganet, dimana analisis ini memungkinkan peneliti untuk melihat pada pendapat individu atau institusi yang mengungkapkan suatu sentimen positif maupun negatif.

Dalam membantu pengerjaan, data dikumpulkan dari media sosial Twitter dengan menggunakan perangkat lunak NCapture yang merupakan sebuah alat tambahan (add-on) yang dapat disematkan pada alat mesin pencarian. NCapture membantu mengumpulkan data dari platform Twitter dengan kata kunci, "wisata buka", dan menghasilkan sebanyak 513 postingan yang terbagi menjadi 297 postingan berupa "Tweet" atau cuitan dan 216 postingan berupa "Retweet" atau cuitan ulang, dalam penelitian 
ini hanya digunakan data yang termasuk kedalam "tweet" atau pesan langsung, sehingga jumlah data yang dianalisis sebanyak 297 postingan. NCapture mengumpulkan data postingan Twitter hanya pada jangka waktu 7 hari, sehingga data yang digunakan dalam penelitian ini pada rentang waktu 17 sampai dengan 25 Desember 2020. Data yang dikumpulkan melalui NCapture merupakan data yang dapat dianalisis dengan menggunakan bantuan perangkat lunak NVivo 14, dengan menggunakan fitur pengkodean secara otomatis dalam pengumpulan sentimen pengguna. Selain itu, NVivo memmungkinkan pengerjaan dalam bentuk pengelompokkan kata-kata berdasarkan jumlah yang sering muncul dan ditulis oleh pengguna Twitter terkait dengan kata kunci yang diinginkan (Indartoyo et al., 2020).

\section{HASIL DAN PEMBAHASAN}

Berdasarkan data yang terkumpul dengan bantuan dari NCapture, dari keseluruhan data didapatkan temuan dalam penelitian ini mengenai penggunaan Twitter di Indonesia. Hasil analisis menunjukkan sebaran pengguna berdasarkan titik koordinat internet pengguna Twitter dalam pencarian ini, ditemukan titik koordinat pengguna Twitter di Indonesia, sedangkan terdapat titik-titik koordinat lain yang tersebar di benua Amerika, Afrika, Australia, Antartika dan negara Jepang juga Korea, dalam penelitian ini penulis memiliki batasan mengenai alasan mengapa terdapat titik koordinat di luar negara Indonesia, sehingga perlu dilakukan kajian lebih lanjut mengenai hal ini. Sedangkan, sebaran koordinat pengguna di wilayah Indonesia menunjukkan bahwa pengguna Twitter di Indonesia berpusat di kota-kota besar dan pulau Jawa (lihat Gambar 1.), berdasarkan data dari Badan Pusat Statistik (BPS) menunjukkan bahwa infrastruktur di Pulau Jawa lebih berkembang dibandingkan di daerah lain di Indonesia, sehingga lebih mempermudah masyarakat mengakses internet (Pratama, 2020).

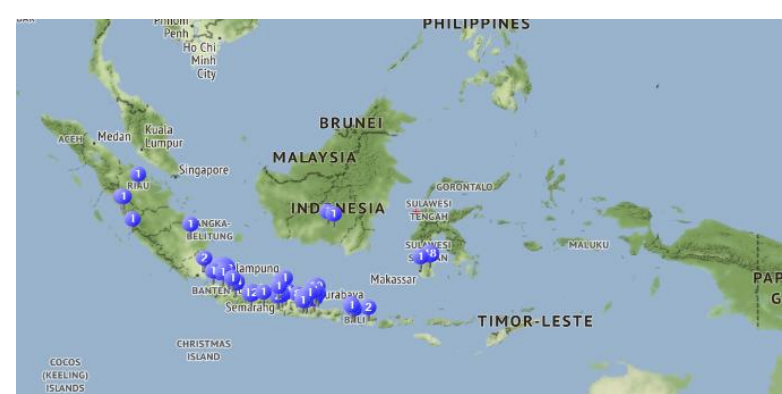

Gambar 1. Peta Sebaran Pengguna Twitter

Tweet atau sebuah pesan pendek yang memiliki batasan berdasarkan karakter yaitu sejumlah 140 karakter yang disediakan oleh Twitter, sebagai media berkomunikasi secara online, yang pada kasus ini dibatasi dengan pencarian teks yaitu "wisata buka" sebagai perwakilan dari fenomena pembukaan pariwisata. Hasil menunjukkan bahwa tweet yang muncul pada pencarian bersumber dari berbagai macam akun, namun akun pribadi menjadi mayoritas sumber tweet yang muncul (lihat Gambar 2), diikuti oleh akun resmi dari berita online nasional, seperti detik.com, kompas.com, tempo.com dan sebagainya, dan akun berita online lokal/daerah, selanjutnya terdapat akun komunitas dan/atau industri pariwisata dan paling sedikit adalah akun pemerintah.

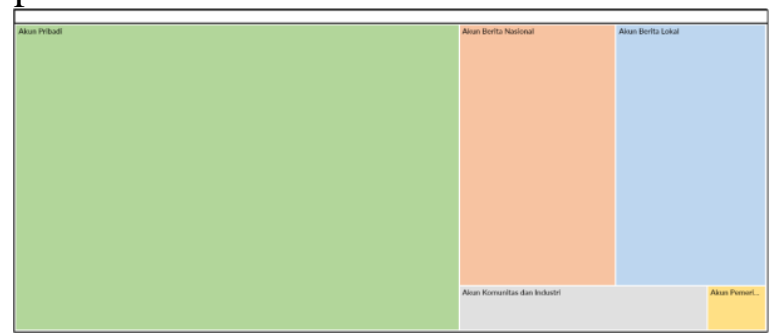

Gambar 2. Chart Berdasarkan Jenis Akun

Temuan lainnya berdasarkan pencarian "mention" sebuah istilah dalam Twitter yang memiliki arti menyebut atau memanggil pengguna Twitter lain dalam sebuah "tweet" (Hadna et al., 2016), hasil proses data menunjukkan terdapat dua publik figur pemerintahan yang disebutkan cukup banyak, yaitu akun Twitter Presiden Republik Indonesia, Joko Widodo (@jokowidodo) dan akun Twitter Gubernur Jawa Tengah, Ganjar Pranowo (@ganjarpranowo) (lihat Gambar 3). Kedua publik figur ini sering muncul dalam tweet warganet terkait dengan pembukaan pariwisata, baik mengenai pesan pertanyaan, kritik, ataupun saran. 
Salah satu contoh kalimat dalam tweet yang disampaikan dengan mention kepada kedua publik figur tersebut antara lain sebagai berikut:

@ VeritasArdentur dengan tweet: “Asal jangan OCOK aja lagi. Dan program2 wisata ke balinya jangan pakai acara buat teriak "buka-buka". https://t.co/GIYuNKVrwT" @ gihgigih18

“@ganjarpranowo dengan @AnggaBadana @ hendrarprihadi Emang candi ne di buka kapan pak? Apik ik saiki wisata anyar, opo meh di gawe konten horor sek pak?"
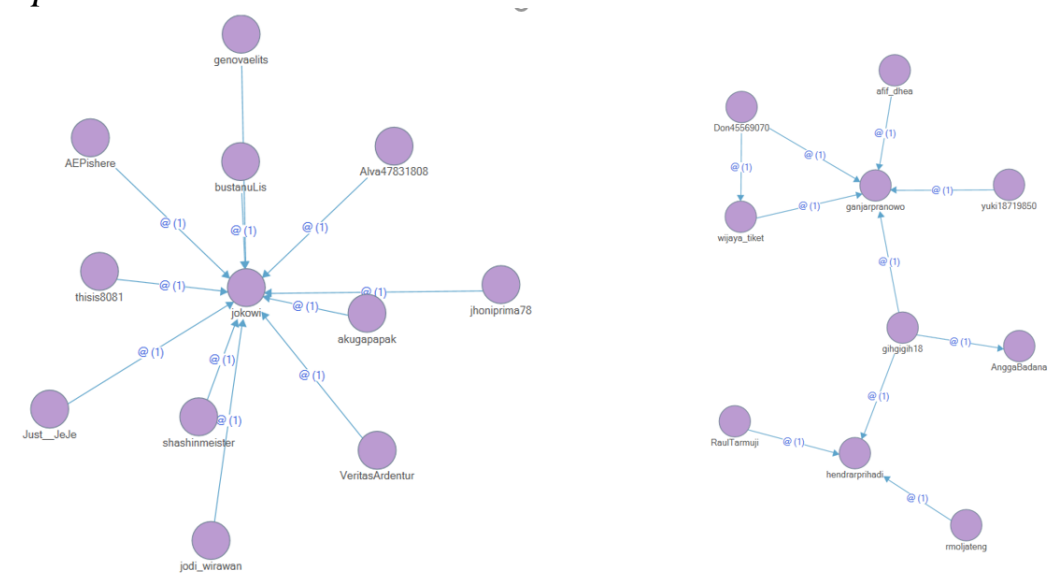

Gambar 3. Sebaran Mention terhadap Akun Publik Figur

Kedua tweet di atas merupakan contoh tweet yang didapatkan dalam data mining menggunakan NCapture dan berkaitan dengan pembukaan kembali pariwisata. Ditujukan secara langsung kepada kedua akun publik figur pemerintahan, dengan konteks mengkritisi dan mengajukan pertanyaan terkait pariwisata di beberapa daerah yaitu Bali dan Jawa Timur.

\subsection{Analisis Menggunakan built in Word Query Coding}

Setelah menemukan 297 postingan berupa tweet maka selanjutnya data dianalisis menggunakan fitur Built in Word Query Coding pada perangkat lunak NVivo 14, yang membantu dalam pemrosesan data dengan menghitung jumlah kata yang paling sering muncul atau disebutkan pada tweet terkait pembukaan pariwisata. Tabel 1 di bawah ini menunjukkan sepuluh kata paling sering diposting di media sosial Twitter dan katakata yang berkaitan dengan konteks penelitian ini, antara lain, wisata; buka; Khofifah (Gubernur Jawa Timur); tempat; gubernur; jatim "Jawa Timur"; kesehatan; libur; protokol; dan nataru "Natal dan Tahun Baru" (lihat Tabel 1).
Tabel 1. Kata yang Paling Sering Muncul

\begin{tabular}{lccc}
\hline Word & Length & Count & $\begin{array}{c}\text { Weigthed } \\
\text { Percentage }(\%)\end{array}$ \\
\hline wisata & 6 & 447 & 4,67 \\
buka & 4 & 412 & 4,30 \\
Khofifah & 8 & 276 & 2,88 \\
tempat & 6 & 199 & 2,08 \\
gubernur & 8 & 198 & 2,07 \\
jatim & 5 & 168 & 1,75 \\
kesehatan & 9 & 119 & 1,24 \\
libur & 5 & 119 & 1,24 \\
protokol & 8 & 114 & 1,19 \\
nataru & 6 & 99 & 1,03 \\
\hline
\end{tabular}

Sumber: Hasil Pengolahan NVivo (2020)

Selain itu, tabel 1 menunjukkan bahwa pengguna Twitter dalam merespon pembukaan pariwisata di masa pandemi, mereka mengaitkan fenomena ini dengan kebijakan yaitu dengan munculnya kata kesehatan dan protokol serta pembuat kebijakannya itu sendiri yaitu dari pemerintah, terlihat dari munculnya nama Khofifah Indar Parawansa, sebagai Gubernur Jawa Timur dan juga kata gubernur, serta dikaitkan dengan lokasi yaitu munculnya Jatim atau akronim dari Jawa Timur. 
Selanjutnya, dikaitkan dengan momen yaitu adanya kata-kata yang muncul seperti libur dan nataru "Natal dan Tahun Baru".

\subsection{Analisis Menggunakan Built in Coding Sentiment and Themes}

Penganalisisan dilanjutkan dengan menggunakan fungsi dari NVivo 14 lainnya, yaitu Built in Coding Sentiment and Themes, analisis untuk mengetahui sentimen pengguna Twitter terhadap fenomena pembukaan pariwisata di tengah pandemi Covid-19. Hasil menunjukkan sebagian besar netral atau tidak berada pada di posisi negatif ataupun positif. Namun, tweet dengan sentimen negatif lebih banyak dibandingkan dengan yang positif (lihat Gambar 4).

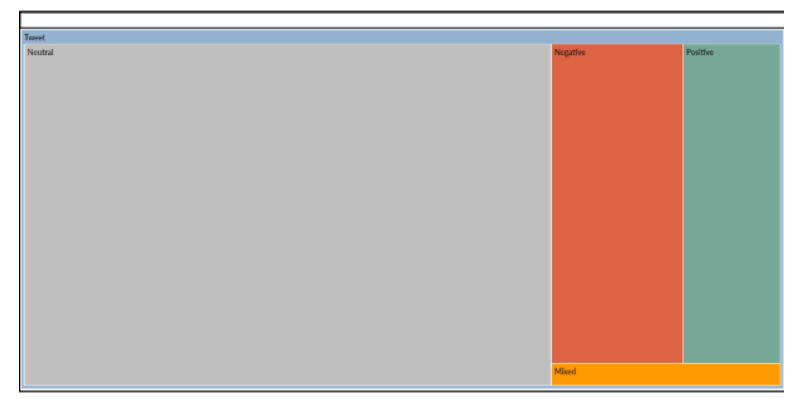

Gambar 4. Hirarki Sentimen Pengguna Twitter

Gambar di atas menjelaskan bahwa dari 297 postingan terbagi menjadi beberapa kelompok seperti postingan dengan konten sentimen netral sebanyak 209 postingan (warna abu-abu), postingan dengan konten sentimen negatif sebanyak 49 postingan (warna merah), postingan dengan konten positif sebanyak 36 postingan (warna hijau), sedangkan postingan dengan konten campuran sebanyak 9 postingan (warna kuning). Maka dapat disimpulkan bahwa berdasarkan hasil analisis sentimen fenomena pembukaan pariwisata di tengah pandemi Covid-19 sebagai sesuatu yang biasa saja tidak salah ataupun benar, atau tidak memihak. Salah satu hasil analisis kepada tweet yang memiliki konten netral adalah tweet yang dituliskan akun @Don45569070 sebagai jawaban (reply) kepada akun @wijaya_tiket yang berisi “@wijaya_tiket @ ganjarpranowo Boss, wisata buka ya gpp to ya, mereka juga berharap cari nafkah.
Susahnya itu ketika sudah di beritahu tp jawabe " urip mati wis ono ngatur ". Lah meh gimana nek jawabane gjtu?". Tweet tersebut mengandung konten netral dikarenakan akun pengguna Twitter tersebut menyebutkan kata berharap dan susahnya, konteks yang ada dalam isi tweet tersebut menunjukkan bahwa opini pengguna akun tersebut menunjukkan sifat tidak berpihak.

Gambar 5 menunjukkan tema atau kata kunci yang sering muncul dalam tweet pencarian "wisata buka" yang terkait dengan pembukaan kembali pariwisata yang terdiri dari kata-kata seperti buka; wisata; tempat wisata; protokol kesehatan; dan wisata air. Peta proyek jalur tweet menunjukkan bagaimana suatu akun membuat sebuah tweet berdasarkan kata kunci serta bagaimana sentimen yang ditunjukkan dalam konten yang mereka buat di Twitter. Kata kunci "wisata","buka", dan "protokol kesehatan" sering muncul pada tweet yang dibuat oleh semua akun baik akun pribadi, akun berita nasional, akun komunitas dan/atau industri pariwisata; akun berita lokal, dan akun pemerintah, hal ini menunjukkan keinginan masyarakat dan pihak lain seperti media, dan pemerintah untuk selalu memberikan informasi mengenai hal-hal tersebut khususnya mengenai protokol kesehatan dan dikarenakan pencarian ini berkaitan dengan pembukaan pariwisata sehingga semua akun lebih besar kemungkinan menggunakan kata kunci "wisata" dan "buka", baik dalam tweet berisi opini, kritik ataupun pertanyaan. Sedangkan untuk kata kunci "tempat wisata" hanya sering muncul pada tweet yang bersumber dari akun pribadi, akun berita nasional, dan akun berita lokal, hasil observasi pada data Twitter menunjukkan penggunaan frasa "tempat wisata" muncul pada akun pribadi dalam konteks bertanya, dan mengkritisi, sedangkan pada akun berita online baik lokal ataupun nasional, berisikan konten mengenai informasi dan berita. Frasa "wisata air" hanya sering muncul di akun selain akun pemerintah, sama halnya dengan frasa "tempat wisata", frasa ini sering muncul dalam konteks berbagi informasi. 


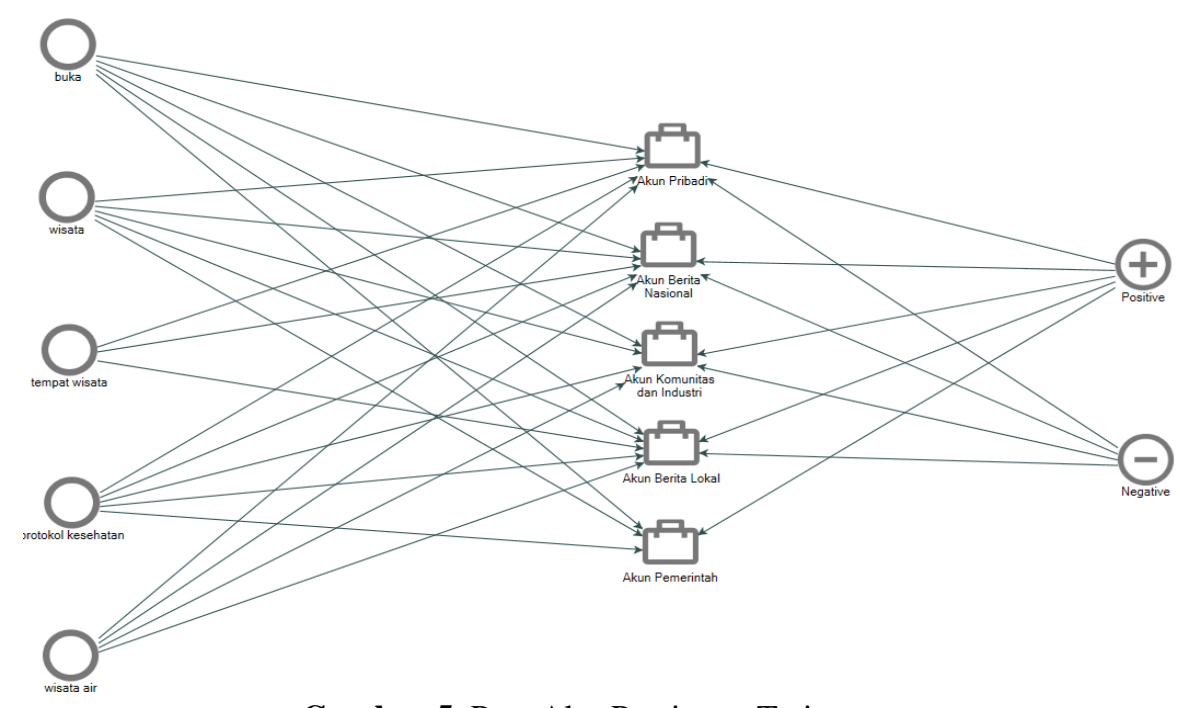

Gambar 5. Peta Alur Postingan Twitter

Dalam konteks sentimen, akun pribadi, akun berita online lokal dan nasional serta akun komunitas dan/atau industri pariwisata sama-sama merupakan sumber tweet dengan sentimen negatif dan positif, sedangkan tidak ada tweet dengan sentimen negatif yang bersumber dari pemerintah. Sebagai pembuat kebijakan, serta memiliki kewajiban untuk memaksimalkan usaha menjaga masyarakat dari pandemi Covid-19 (Harirah \& Rizaldi, 2020), sehingga penggunaan media sosial lebih sebagai media komunikasi terkait kebijakan, dan perkembangan dari penanganan Covid-19. Namun, mengenai keefektifan saluran informasi melalui media sosial yang dilakukan pemerintah belum banyak diteliti, sehingga dapat menjadi topik dalam penelitian selanjutnya.

\section{SIMPULAN}

Fenomena pembukaan kembali pariwisata pada sudut pandang pengguna Twitter yang dianalisis menggunakan bantuan perangkat lunak NVivo 14 dengan pendekatan metode netnografi, menunjukkan sentimen pengguna Twitter atau warganet. Hasil analisis menunjukkan sebagian besar warganet memberikan sentimen netral terkait pembukaan kembali pariwisata atau berada pada posisi tidak memihak. Penelitian ini juga menunjukkan beberapa kata dan frasa yang sering muncul seperti "wisata", "buka" dan "protokol kesehatan". Menariknya, hasil temuan penelitian ini menunjukkan di antara akun Twitter yang ada hanya akun pemerintahan yang tidak memiliki sentimen negatif dalam tweet yang dibuatnya. Perlu dilakukan penelitian lebih lanjut mengenai posisi netral warganet dalam postingannya di Twitter, guna memperdalam kondisi netral yang didapat apakah diakibatkan oleh sikap apatis masyarakat, atau keberadaan masyarakat yang sudah mulai bosan dan terbiasa dengan keadaan seperti di era new normal ini ataupun alasan lainnya yang perlu ditelusuri kembali.

Hasil temuan dari analisis sentimen pengguna Twitter ini, dapat dijadikan arahan untuk mengetahui sikap dan respon masyarakat terhadap pembukaan kembali pariwisata di tengah pandemi Covid-19. Pembentukan opini publik dengan cepat dapat terpengaruh oleh konten-konten yang tersebar melalui media sosial, kecepatan dan ketepatan sasaran informasi yang beredar di media sosial dapat membentuk opini menuju sentimen negatif ataupun positif. Pemerintahan yang dapat menindaklanjuti ini dengan cepat, akan besar kemungkinannya untuk terhindar dari kondisi krisis darurat publik, karena sudah mengetahui gambaran opini dan respon dari kebijakan yang akan ataupun telah dilaksanakan. Sentimen yang muncul dalam konten tertulis di media sosial dapat dijadikan acuan untuk analisis 
kemungkinan kejadian serta cara mengatasinya, dan sebagai bentuk antisipasi terhadap kejadian yang dapat terjadi di masa depan. Penggunaan sentimen penggunaan Twitter dalam kasus pariwisata, secara spesifik dapat digunakan sebagai media eksplorasi untuk penelitian selanjutnya, yang dapat dilakukan seperti 1) analisis keefektifan media sosial pemerintah dalam penyebarluasan informasi mengenai Covid-19 dan protokol kesehatan; 2) analisis opini publik terhadap kegiatan pariwisata atau perjalanan yang dilakukan orang sekitar atau publik figur; dan sebagainya.

\section{UCAPAN TERIMA KASIH}

Artikel ini menggunakan tweet dari beberapa akun Twitter yang muncul dalam pencarian dengan kata kunci yang digunakan. Oleh karena itu, pada kesempatan ini, penulis hendak menyampaikan terima kasih kepada seluruh akun media sosial Twitter yang muncul dan tercantum dalam penelitian ini.

\section{REFERENSI}

Aditya, H., Ardiansyah, Sidik, \& Gata, W. (2020). Analisis Sentimen Penggunaan Twitter Terhadap Penggunaan Cairan Desinfektan Menggunakan Metode Term Frequency - Inverse Document Frequency Dan Support Vector Machine. Jurnal Ilmu-Ilmu Informatika Dan Manajemen, 14(2), 167-174.

Aditya, N. R. (2020). Pariwisata Buka Saat New Normal, Ini Hal-hal yang Harus Diketahui. Kompas.Com. https://travel.kompas.com/read/2020/05/ 29/154500227/pariwisata-buka-saatnew-normal-ini-hal-hal-yang-harusdiketahui?page $=$ all

Agustino, L. (2020). Analisis Kebijakan Penanganan Wabah Covid-19: Pengalaman Indonesia Analysis Of Covid-19 Outbreak Handling Policy: The Experience Of Indonesia. Junal Borneo Administrator, 16(2), 253-270.

Ahuja, V., \& Shakeel, M. (2017). Twitter Presence of Jet Airways-Deriving Customer Insights Using Netnography and Wordclouds. Procedia Computer
Science, 122 , $17-24$. https://doi.org/10.1016/j.procs.2017.11. 336

Alizah, M. D., Nugroho, A., Radiyah, U., \& Gata, W. (2020). Sentimen Analisis Terkait "Lockdown" pada Sosial Media Twitter. CSRID Journal, 12(3), 143-149.

Alkatiri, A. B. M., Nadiah, \& Nasution, A. N. S. (2020). Opini Publik Terhadap Penerapan New Normal Di Media Sosial Twitter. CoverAge, 11(1).

Anderson, R. M., Heesterbeek, H., Klinkenberg, D., \& Hollingsworth, T. D. (2020). How will country-based mitigation measures influence the course of the COVID-19 epidemic? In Elsevier (Vol. 395, Issue March 21).

Bowler Jr, G. M. (2010). Netnography: A method specifically designed to study cultures and communities online. The Qualitative Report, 15(5), 1270.

CNBC Indonesia. (2020). Inilah Kata Influencer Soal Insentif Wisata Untuk Hadapi Corona. CNBC Indonesia TV. https://www.cnbcindonesia.com/news/2 0200304135044-8-142429/ini-katainfluencer-soal-insentif-wisata-untukhadapi-corona

Hadna, M. S., Santosa, P. I., \& Winarno, W. W. (2016). Studi Literatur Tentang Perbandingan Metode Untuk Proses Analisis Sentimen Di Twitter. Seminar Nasional Teknologi Informasi Dan Komunikasi, 2016(Sentika), 57-64. https://fti.uajy.ac.id/sentika/publikasi/m akalah/2016/95.pdf

Hanafi, I., \& Ferdiansyah, R. (2020). Sentimen Analisis Twitter pada Hastag PSBB di Indonesia dalam Menghadapi Pandemi Covid-19. Jurnal Informatika Dan Sistem Informasi (JIFoSI), 1(3), 1011-1022.

Harirah, Z., \& Rizaldi, A. (2020). Merespon Nalar Kebijakan Negara Dalam Menangani Pandemi Covid 19 Di Indonesia. Jurnal Ekonomi Dan Kebijakan Publik Indonesia, 7(1), 3653.

https://doi.org/10.24815/ekapi.v7i1.173 70 
Ihsanuddin. (2020). Buka Pariwisata di Tengah Pandemi, Kebijakan Berisiko yang Tetap Diambil. Kompas.Com. https://nasional.kompas.com/read/2020/ 05/29/08465791/buka-pariwisata-ditengah-pandemi-kebijakan-berisikoyang-tetap-diambil?page $=$ all

Indartoyo, I. M., Kim, D. W., Purwanto, B. M., Gunawan, A., Riantini, R. E., \& Gea, D. (2020). Netnography analysis of consumer sentiment towards panic buying in the early period of the COVID19 virus spread. Proceedings of 2020 International Conference on Information Management and Technology, ICIMTech 2020, August, 626-631. https://doi.org/10.1109/ICIMTech50083 .2020 .9211182

Kozinets, R. V. (2015). Netnography. The International Encyclopedia of Digital Communication and Society, 1-8. https://doi.org/10.1002/9781118767771. wbiedcs 067

Maulida, F., Ginting, I. R., Ulfah, I. A., Elfiyani, N. K., Dara, P., \& Pratomo, H. (2020). Analisis Kebijakan Global Travel Warning Selama Pandemi Covid19 dan Implementasinya di Indonesia. Jurnal Kesehatan, 14(47), 85-100. https://doi.org/10.36082/qjk.v14i2.

Peraturan Menteri Kesehatan Nomor 9 Tahun 2020 tentang Pedoman Pembatasan Berskala Besar (PSBB), (2020).

Napitupulu, A., Embi, M. A., \& Briando, B. (2020). Public Sentiment Analysis on the Existence of Foreign Worker During the Covid 19 Pandemic. October.

Ning, Z. (2020). Public Opinions on the Tourism Industry in the Post-Covid-19 Period: Inherent Features and Guiding Strategies. Iceesr, 419-424. https://doi.org/10.25236/iceesr.2020.082

Parsons, W. (2008). Public Policy: pengantar teori dan praktik analisis kebijakan. Kencana.

Pratama, A. M. (2020). Pengguna Internet Indonesia hingga Kuartal II 2020 Capai 196,7 Juta Orang. Kompas.Com. https://money.kompas.com/read/2020/1 1/09/213534626/pengguna-internet- indonesia-hingga-kuartal-ii-2020-capai1967-juta-orang

Rahma, A. F., Wibowo, A. R. W., \& ... (2020). Analisis Sentimen Hashtag "Dirumahaja" Saat Pandemi Covid-19 Di Indonesia Menggunakan Nlp. Jurnal Informatika Dan Sistem Informasi (JIFoSI)..., 1(2), 343-353. http://jifosi.upnjatim.ac.id/index.php/jif osi/article/view/239

Santia, T. (2020). Bayar Influencer Rp. 72 Miliar, Promosi Pariwisata Indonesia Dinilai Efektif. Liputan 6. https://www.liputan6.com/bisnis/read/4 189832/bayar-influencer-rp-72-miliarpromosi-pariwisata-indonesia-dinilaiefektif

Shalihah, N. F. (2020). Bagaimana Protokol Kesehatan di Tempat Wisata Saat New Normal? Kompas.Com. https://www.kompas.com/tren/read/202 0/06/18/080500265/bagaimanaprotokol-kesehatan-di-tempat-wisatasaat-new-normal-?page $=$ all

Shorey, S., Ang, E., Yamina, A., \& Tam, C. (2020). Perceptions of public on the COVID-19 outbreak in Singapore: a qualitative content analysis. Journal of Public Health (Oxford, England), 42(4), 665-671.

https://doi.org/10.1093/pubmed/fdaa105

Syarifuddin, K. T. (2020). Sarkasme pada masyarakat indonesia selama pandemi covid-19 dalam media sosial twitter. Prosiding Seminar Bahasa Dan Sastra Indonesia (SENASBASA), 4, 66-79.

Wahyudi, E. (2020). Promosikan Pariwisata RI, Wishnutama Gandeng Influencer Asing. Tempo Bisnis. https://bisnis.tempo.co/read/1313738/pr omosikan-pariwisata-ri-wishnutamagaet-15-influencer-asing

Yurianto, A., Pritasari, K., Wibowo, B., \& Siswanto. (2020). Pedoman Penanganan Cepat Medis Dan Kesehatan Masyarakat COVID-19 Di Indonesia. https://covid19.go.id/p/protokol/pedoma n-penanganan-cepat-medis-dankesehatan-masyarakat-covid-19-diindonesia 